\title{
Our Contributors / Nos collaborateurs
}

MARCEL LAJEUNESSE est professeur titulaire à l'Ecole de bibliothéconomie et des sciences de l'information de l'Université de Montréal.

DOUglas G. LOCHHEAD is Davidson Professor and Director of Canadian Studies at Mount Allison University, Sackville, New Brunswick, and a former President of the Society.

LIANA VAN DER BELLEN is Chief of the Rare Book Division in the National Library of Canada and a former President of the Society.

BRUCE WHITEMAN is Research Collections Librarian, McMaster University Library, Hamilton, Ontario. His descriptive bibliography of the work of Raymond Souster was published in I984 by Oberon Press. 